\title{
PARAMETERS OF FREE-RADICAL OXIDATION AND ANTIOXIDANT DEFENCE SYSTEM IN RATS OF BOTH SEXES WITH SODIUM NITRITE INTOXICATION
}

Long-term influence of sodium nitrite on rats causes an increase in lipid peroxidation products in blood and myocardial tissue in animals of both sexes and is accompanied by a decrease in activity of enzymic and non-enzymic components of antioxidant defence system. Under the conditions of intoxication, the process of $L P O$ is less aggressive in females in the comparison with males.

KEY WORDS: lipid peroxidation, sodium nitrite, sex, myocardium.

INTRODUCTION. For the last several decades nitrates and nitrites have occupied a priority position among environmental pollutants resulting from the intensification of agriculture, food industry, imperfections of waste treatment facilities, violations of storage regulations and the use of nitrogen fertilizers as well as air pollution with nitrogen oxides, etc. $[2,5,14]$.

Nitrites are able to affect the body at its all structural and functional levels, beginning with the whole organism, its tissues, cells and separate molecules. The basis of the systemic mechanisms of this effect is the reaction of converting nitrite ions into $\mathrm{NO}$ [9]. In case of excessive NO content, NO is converted from cytoprotective agent into cytotoxic [14].

The main parameter for estimation of the presence of oxidative stress is the accumulation of primary and secondary products of free-radical oxidation. Imbalance between processes of lipid peroxidation (LPO) and antioxidant defence system causes avalanche-like reaction of peroxidation, resulting in deviations in the structure and function of cell membranes and the death of the cell. This process reflects one of the non-specific phases of pathogenesis that underlies many pathological conditions, including necrotizing cardiomyocytes. The activity of the given process along with the structural analysis allows estimation of the intensity of myocardium destruction [12].

In recent years, sex-based differences in course and treatment of various diseases have been intensively discussed. This is especially true of cardiological disorders since the differences in risk factors, clinical manifestations, diagnostic and

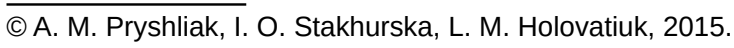

therapeutic approaches in men and women are pronounced most of all in case of cardiovascular diseases $[1,6,13]$.

Therefore, the aim of our investigation was to study the peculiarities of the parameters of freeradical oxidation and antioxidant defence system in blood and myocardium tissue of male and female rats with sodium nitrite intoxication.

METHODS OF RESEARCH. The given research was carried out on 24 mature nonlinear white rats, in compliance with the rules of European Convention for the Protection of Vertebrate Animals used for Experimental and other Scientific Purposes (1986) [11]. Toxic influence was modelled by intragastric administration of sodium nitrite every day for three weeks in the form of aqueous solution at a dose of $5 \mathrm{mg} / \mathrm{kg}$ of body weight [8]. Euthanasia of rats was performed by bloodletting under the conditions of thiopental sodium anaesthesia. To study the peculiarities of free-radical oxidation and antioxidant defence system, the content of TBA-active products (TBA-AP), conjugated diene and triene (CD, CT), activity of superoxide dismutase (SOD), catalase and ceruloplasmin was determined. Blood plasma, supernatant of erythrocyte hemolisates and myocardial tissue homogenate were investigated.

Statistical analysis was done using Statsoft STATISTICA by the Department of System Investigations of I. Ya. Horbachevsky Ternopil State Medical University. For all indices the arithmetic mean of the sample $(\mathrm{M})$, its variance and average error (m) were calculated. The reliability of differences between the studied parameters was determined by using two-sample Student's t test. 
RESULTS AND DISCUSSION. The results of determination of the parameters of LPO in blood plasma and myocardial tissue homogenate of control group animals and rats with sodium nitrite intoxication are presented in Figure 1-2.

When comparing the parameters of lipid peroxidation in blood plasma of control group females and males we have found lower values in females. Thus, the content of TBA-AP of males is $20.57 \%$ higher than that of females $(p<0.05)$. Regarding conjugated diene and triene, their content in male group was also $16.00 \%$ and $11.27 \%$ higher than that of female. When comparing LPO parameters in control group, in the myocardial tissue homogenate sex-based differences were even more pronounced.
The content of TBA-AP in males was $25.56 \%$ higher than that of females $(p<0.05), C D-21.5 \%$ $(p<0.05), C T-20.79 \%(p<0.05)$. Thus, the process of lipid peroxidation is more intensive in males than in females.

Under the influence of sodium nitrite intoxication, the increase of all parameters of lipid peroxidation is observed both in blood and myocardial tissue homogenate. The most pronounced changes were observed in the level of TBA-AP. Thus, in blood plasma of males this parameter was significantly increased by a factor of 2.4 and that of females by a factor of 2.1. Regarding the myocardial tissue, the content of TBA-AP in males was significantly increased by a factor of 4.1 , and in females - by 3.7 .

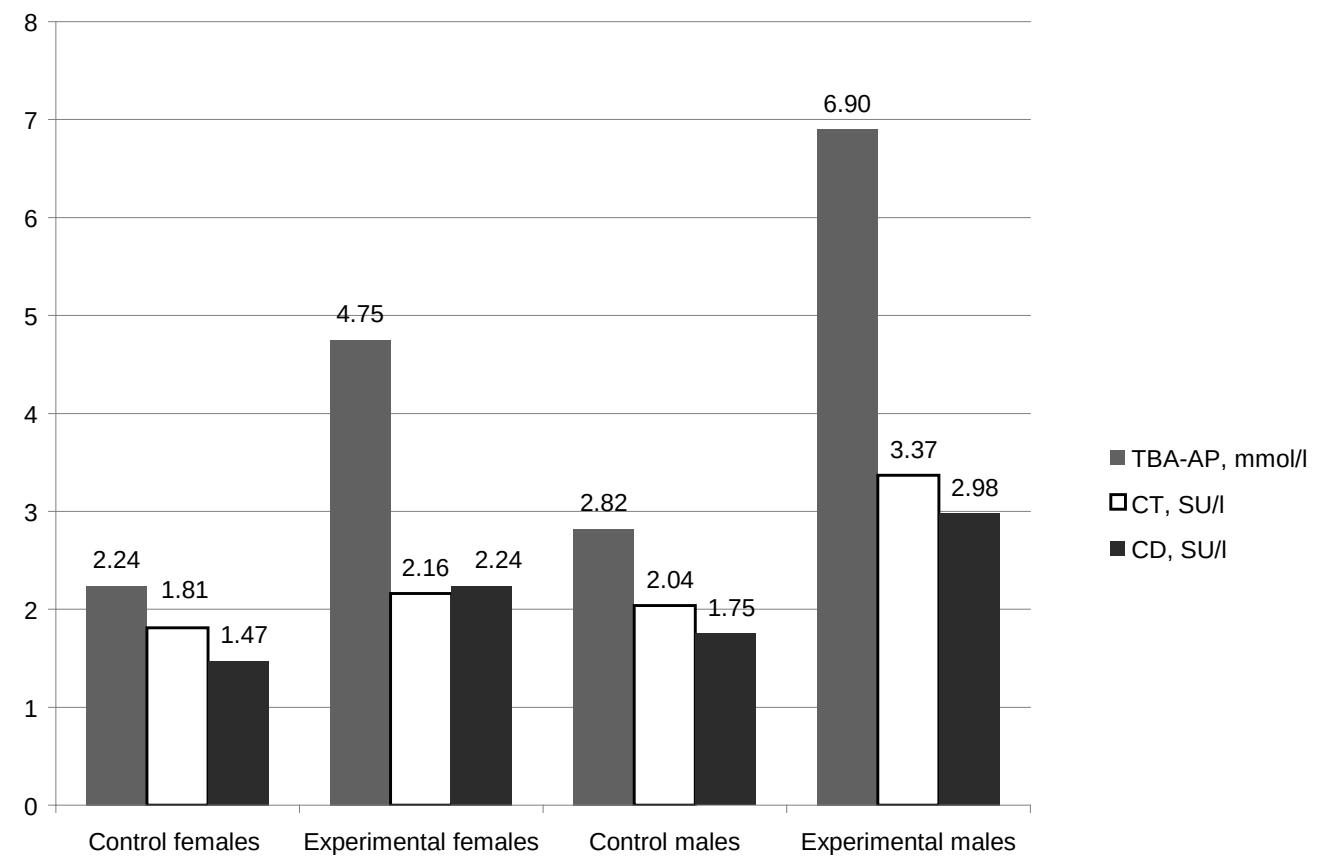

Figure 1. Parameters of lipid peroxidation in rats with sodium nitrite intoxication (blood plasma).

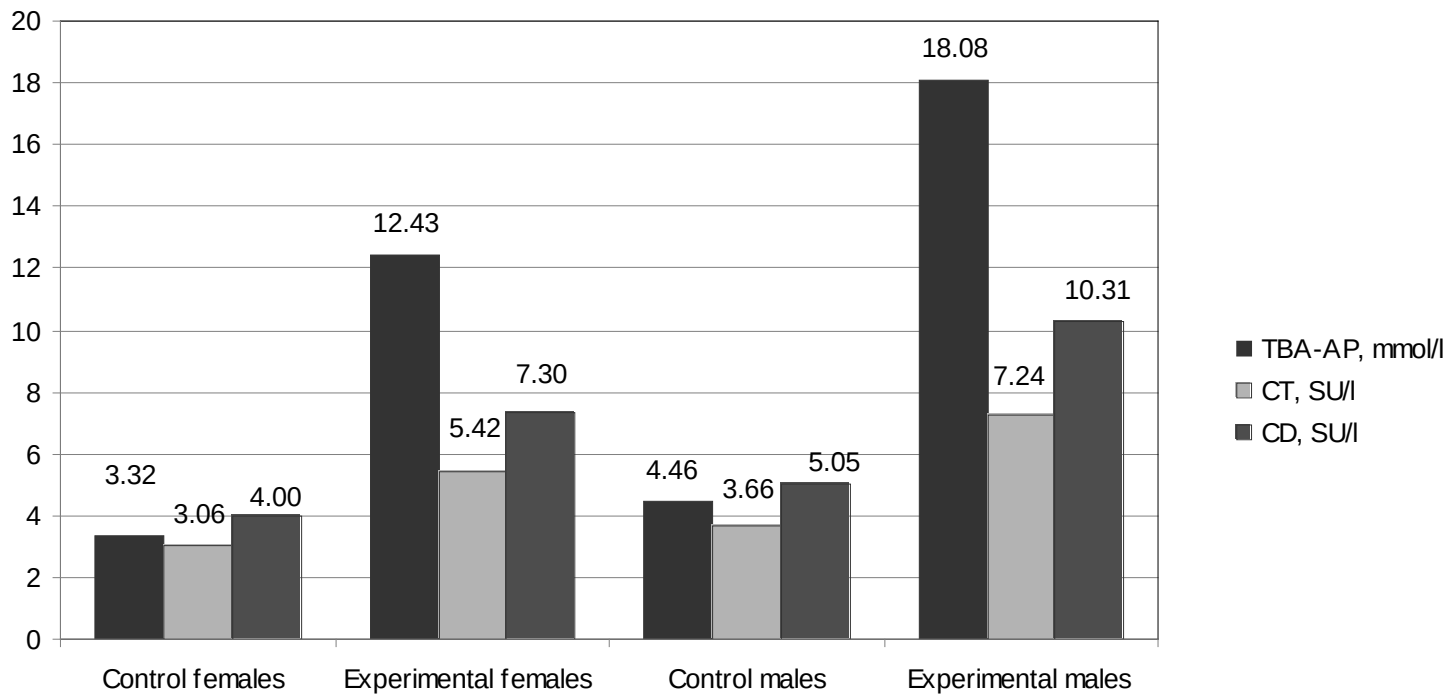

Figure 2. Parameters of lipid peroxidation in rats with sodium nitrite intoxication (myocardial homogenate). 
The results of determination of the parameters of antioxidant defence system in rats with sodium nitrite intoxication are presented in Figure 3-5.

Increased lipid peroxidation and excessive accumulation of its products were connected with the suppression of antioxidant defence system with its enzymatic components SOD and catalase. When comparing the parameters of both enzymatic and non-enzymatic components of antioxidant defence system in blood plasma of control group females and males, we determined lower values in males. Thus, SOD activity in females was $56.06 \%$ higher than that of males $(p<0.05)$. The content of ceruloplasmin also significantly exceeded its level in males $(50.00 \%)$. When comparing parameters of antioxidant defence system of control group rats, sex-based differences in the myocardial tissue homogenate were more pronounced. SOD activity in females was $73.64 \%$ higher than that of males. Regarding catalase, we did not find significant

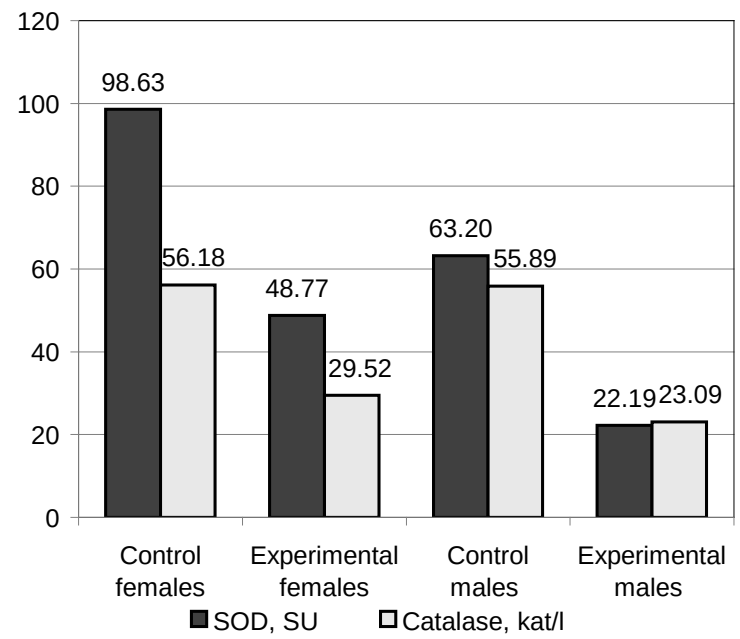

Figure 3. Parameters of antioxidant defence system in rats with sodium nitrite intoxication (supernatant of erythrocyte hemolisates). sex-based differences in its activity either in blood plasma or in myocardial tissue homogenate.

Under the influence of sodium nitrite intoxication, SOD and catalase activity in the supernatant erythrocyte hemolisate was significantly diminished. Thus, SOD activity in male rats significantly decreased by a factor of 2.8 , while in female rats by a factor of 2 . As to the catalase, its activity in male rats significantly decreased by a factor of 2.4 , while in rat females - by a factor of 1.9 .

In the myocardial tissue homogenate, the changes in the activity of enzymatic component of antioxidant defence system tended to be similar, but more pronounced. Taking into consideration antioxidant activity of oestrogen, lower rates of lipid peroxidation in females can be attributed to higher capacity of females' antioxidant system [10]. It has been recently shown that mitochondria possess oestrogen receptors, and chronic use of oestrogen promotes energy production and reduces oxidative

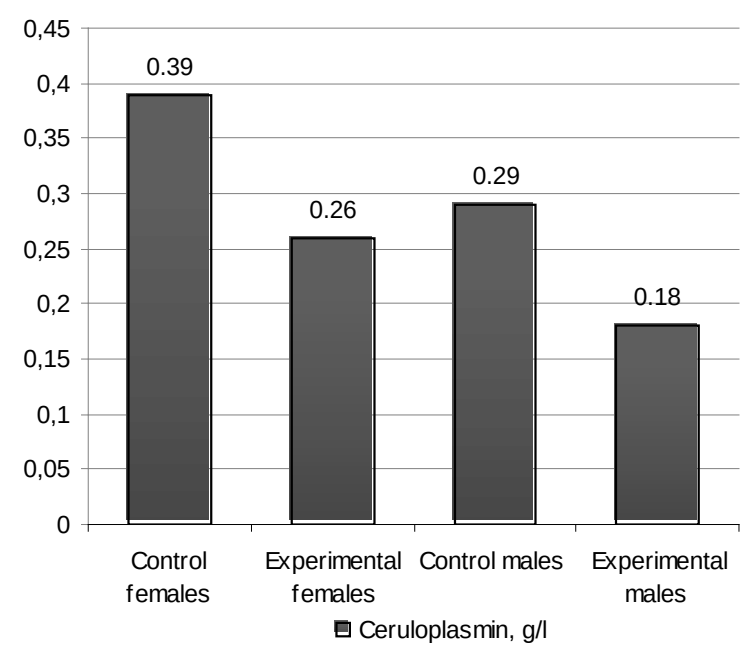

Figure 4. Parameters of antioxidant defence system in rats with sodium nitrite intoxication (blood plasma).

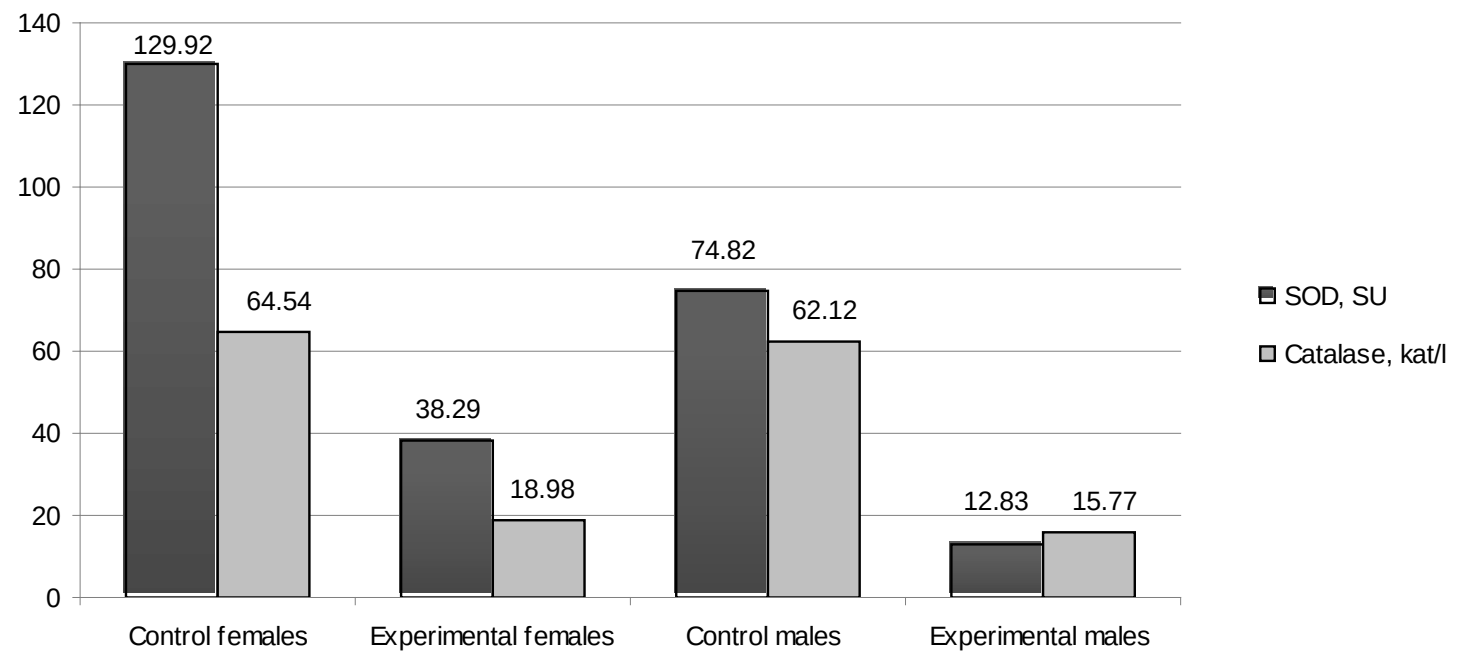

Figure 5. Parameters of antioxidant defence system in rats with sodium nitrite intoxication (miocardial homogenate). 
stress and intensity of apoptosis in the endothelium under the conditions of hypooestrogenia [4].

Our data are consistent with the works of scientists who point to sex-based differences in freeradical oxidation in liver mitochondria [3]. Nitrites, forming active forms of oxygen, contribute to the exhaustion of antioxidant reserve of a cell and multiple defects in cytoplasm membrane [7]. The content of ceruloplasmin in male rats with sodium nitrite intoxication significantly decreased (41.4\%); in females $-31.7 \%(p<0.05)$. High content of ceruloplasmin in females, even with underlying sodium nitrite intoxication, probably can be explained by the fact that ceruloplasmin synthesis is stimulated by oestrogen (M. Kataoka, 1984).

Biochemical characteristics of intoxication are accompanied by morphological manifestations in the form of vascular disorders, alternative and infiltrative processes in the myocardium.

\section{REFERENCES}

1. Camper-Kirby D. Myocardial Akt activation and gender: increased nuclear activity in females versus males / D. Camper-Kirby // Circ. Res. - 2001. - 88 (10). P. 1088-1020.

2. Machha A. Inorganic nitrate: a major player in the cardiovascular health benefits of vegetables? I A. Machha, A. N. Schechter // Nutr. Rev. - 2012. - 70 (6). - P. 367-372.

3. Mitochondria from females exhibit higher antioxidantgene expression and lower oxidative damagethan males / C. Borras, J. Sastre, D. Garcia-Sala [et al.] // Free Radical Research. - 2003. - 34, № 5. - P. 546-552.

4. Saltiki K. Coronary heart disease in postmenopausal women; the role of endogenous estrogens and their receptors / K. Saltiki, M. Alevizaki // Hormones. 2007. - 6, № 1. - P. 9-24.

5. Бабієнко В. В. Особливості функціонування циклу оксиду азоту в умовах впливу його прекурсорів на пренатальному етапі у експериментальних тварин / В. В. Бабієнко // Досягнення біології та медицини. 2013. - 1 (21). - C. 7-10.

6. Барна О. М. Статеві відмінності ведення пацієнтів з артеріальною гіпертензією / О. М. Барна // Мистецтво лікування. - 2009. - № 3 (59). - С. 76-80.

7. Дзахова Г. А. Возрастная динамика цитологических показателей симпатических нейронов в условиях воздействия нитритов и нитратов : автореф. дисс. на соискание учен. степени канд. мед. наук / Г. А. Дзахова. - М., 2005. -22 c.

8. Динамика диуреза и гистоморфоологических изменений почек у белых крыс при хронической интоксикации нитритом натрия / Л. А. Акоева, Л. А. Ги-
CONCLUSIONS. 1. Under the influence of sodium nitrite intoxication the intensification of lipid peroxidation (increased levels of TBA-AP and conjugated dienes and trienes) is observed in blood and myocardial tissue in animals of both sexes.

2. In the experiment, toxic influence of sodium nitrite is accompanied by decreased activity of both enzymic (SOD, catalase) and non-enzymic (ceruloplasmin) components of the antioxidant defence system, indicating the depletion of antioxidant reserves in animals of both sexes.

3. In sex-based comparison of changes in the parameters of lipid peroxidation system under the conditions of sodium nitrite intoxication, their significant prevalence in male rats was found out; as to the parameters of antioxidant defence system, their significant prevalence in female rats was determined. реева, И. Г. Джиоев, Л. С. Таболова // Журн. анатомии и гистопатологии. - 2012. - 1, № 4. - С. 63-65.

9. Иванова А. С. Состояние эритроцитарной системы крыс при хронической нитритной интоксикации и введении альсра-токофрерола : автореф. дис. на соискание учен. степени канд. мед. наук / А. С. Иванова. - СПб, 2008. - 21 с.

10. Мажитова М. В. Возрастные и половые особенности свободнорадикальных процессов и антиоксидантной защиты плазмы крови белых крыс / М. В. Мажитова, Д. Д. Теплый // Естественные науки. 2010. - № 1 (30). - С. 79-85.

11. Науково-практичні рекомендації з утримання лабораторних тварин та роботи 3 ними / Ю. М. Кожем'якін, О. С. Хромов, М. А. Філоненко, Г. А. Сайсретдінова. - К. : Авіцена, 2002. - 156 с.

12. Продукти вільнорадикального перекисного окиснення та методи їх ідентифрікації (огляд літератури) / І. Ф. Бєленічев, Є. Л. Левицький, С. І. Коваленко [та ін.] // Совр. пробл. токсикол. - 2002. № 4. - C. 9-13.

13. Хара М. Р. Статеві відмінності метаболічних змін у міокарді щурів з експериментальним гіпотиреозом, викликаних гонадектомією та корегованих замісною гормонотерапією / М. Р. Хара, В. М. Михайлюк // Клініч. та експерим. патол. - 2012. - 11, № 2 (40). C. 152-158.

14. Хопта Н. С. Особливості метаболізму кісткової тканини щурів за умов нітритної інтоксикації / Н. С. Хопта, Г.М.Ерстенюк // Наукові записки Тернопільського національного педагогічного університету. Серія "Біологія". - 2010. - № 1 (42). - С. 111-117. 
А. М. Пришляк, І. О. Стахурська, Л. М. Головатюк ТЕРНОПІЛЬСЬКИЙ ДЕРЖАВНИЙ МЕДИЧНИЙ УНІВЕРСИТЕТ ІМЕНІ І. Я. ГОРБАЧЕВСЬКОГО

\section{ПОКАЗНИКИ ВІЛЬНОРАДИКАЛЬНОГО ОКИСНЕННЯ ТА СИСТЕМИ АНТИОКСИДНОГО ЗАХИСТУ В ЩУРІВ ОБОХ СТАТЕЙ ЗА УМОВИ ТОКСИЧНОГО УРАЖЕННЯ НАТРІЮ НІТРИТОМ}

\section{Резюме}

Довготривала дія на організм щурів натрію нітриту викликає збільшення кількості продуктів пероксидного окиснення ліпідів у крові та тканині міокарда тварин обох статей і супроводжується зниженням активності показників як фрерментної, так і неферментної ланок системи антиоксидного захисту. В щурів-самок за умов отруєння перебіг процесів пероксидного окиснення ліпідів відбувається менш агресивно порівняно із самцями.

КЛЮчОВІ СЛОВА: пероксидне окиснення ліпідів, натрію нітрит, стать, міокард.

А. М. Пришляк, И. О. Стахурская, Л. М. Головатюк ТЕРНОПОЛЬСКИЙ ГОСУДАРСТВЕННЫЙ МЕДИЦИНСКИЙ УНИВЕРСИТЕТ ИМЕНИ И. Я. ГОРБАЧЕВСКОГО

\section{ПОКАЗАТЕЛИ СВОБОДНОРАДИКАЛЬНОГО ОКИСЛЕНИЯ И СИСТЕМЫ АНТИОКСИДНОЙ ЗАЩИТЫ У КРЫС ОБОЕГО ПОЛА В УСЛОВИЯХ ТОКСИЧЕСКОГО ПОРАЖЕНИЯ НАТРИЯ НИТРИТОМ}

\section{Резюме}

Длительное воздействие на организм крыс натрия нитрита вызывает увеличение количества продуктов пероксидного окисления липидов в крови и ткани миокарда животных обоего пола и сопровождается снижением активности показателей как фрерментного, так и неферментного звеньев системы антиоксидной защиты. У крыс-самок в условиях отравления течение процессов пероксидного окисления липидов происходит менее агрессивно по сравнению с самцами.

КЛЮЧЕВЫЕ СЛОВА: пероксидное окисление липидов, натрия нитрит, пол, миокард.

Received 16.03.15

Address for correspondence: A. M. Pryshliak, I. Ya. Horbachevsky Ternopil State Medical University, Maidan Voli, 1, Ternopil, 46001, Ukraine. 